\title{
Prestígio escolar e composição de turmas - explorando a hierarquia em redes escolares ${ }^{1}$
}

\author{
MARCIO DA COSTA \\ UFRJ
}

MARIANE C. KOSLINSKI

UFRJ

\section{RESUMO}

No Brasil, há uma evidente hierarquia entre o alunado das redes escolares do ensino básico. Normalmente, as escolas privadas tendem a acolher alunos de melhor nível socioeconômico, ocupando as redes estaduais e municipais, sucessivamente, posiçóes inferiores em uma escala de recursos econômicos de seus públicos. Entretanto, também existe forte hierarquização no interior das redes públicas e das instituiçóes escolares. Essas hierarquias correspondem a um complexo sistema de produçáo e alimentação de desigualdades que no âmbito escolar, das oportunidades e da inserção a posteriori na estrutura ocupacional, desenha um esboço da marcante desigualdade social brasileira. O objetivo deste artigo é apresentar e descrever achados de uma pesquisa que explorou esse pouco conhecido universo das diferenças intra e entre escolas, para além dos aspectos relativos ao desempenho do alunado, enfatizando dimensóes culturais e referentes à trajetória escolar pregressa. A pesquisa utilizou diversos instrumentos de coleta de informaçóes, mas este texto apresenta parte dos resultados extraídos de um survey com cerca de 2500 alunos de vinte escolas do Rio de Janeiro. Os resultados indicam não só a óbvia diferenciação socioeconômica do alunado, mas também a presença de elementos culturais relevantes e de um presumível efeito da experiência de escolarização sobre perspectivas e atitudes dos alunos.

Palavras-chave: prestígio escolar, hierarquias escolares, diferenciação entre turmas.

${ }^{1}$ Trabalho financiado com recursos do CNPq, nos termos do Edital Universal 2005. 


\section{RESUMEN}

En Brasil existe una evidente jerarquía entre el alumnado de las redes escolares de la enseńanza básica. Normalmente, las escuelas privadas tienden a acoger alumnos de un nivel socioeconómico mejor. Las redes estaduales y municipales ocupan, sucesivamente, posiciones inferiores en una escala de recursos económicos de su público. Sin embargo, también existe una fuerte jerarquía en el interior de las redes públicas y de las instituciones escolares. Estas jerarquías corresponden a un complejo sistema de producción y alimentación de las desigualdades que en el ámbito escolar, de las oportunidades y de la inserción a posteriori en la estructura ocupacional, diseña un esbozo de la marcada desigualdad social brasileńa. El objetivo de este artículo es presentar y describir descubrimientos de una investigación que indagó sobre ese universo poco conocido de las diferencias intra y entre escuelas, más allá de los aspectos relativos al desempeño del alumnado, enfatizando dimensiones culturales y referentes a la trayectoria escolar anterior. La investigación utilizó diversos instrumentos de recolección de datos, pero este texto presenta una parte de los resultados extraídos de un survey con cerca de 2.500 alumnos de veinte escuelas de Rio de Janeiro. Los mismos muestran no sólo la obvia diferencia socioeconómica de los alumnos, sino también la presencia de elementos culturales relevantes y de un presumible efecto de la experiencia de escolarización, sobre las perspectivas y actitudes de los alumnos.

Palabras clave: prestigio escolar, jerarquías escolares, diferenciación entre clases.

\section{ABSTRACT}

There is a clear hierarchy among students of the basic education school networks in Brazil. Normally, private schools tend to accommodate students who are socioeconomically better off, while state and municipal networks stand in lower positions on the scale of their students' economic resources. However, there is also a clear hierarchy within public networks and within school institutions. These hierarchies are a complex system of producing and fostering inequality which, in the realm of school opportunities and future insertion into an occupational structure, draws a picture of striking Brazilian social inequality. This paper will present and describe findings of a survey that explored this little-known universe of differences within and between schools, beyond matters relating to the performance of students, emphasizing cultural dimensions relating to their previous school life. The survey used different instruments for collecting information, but this text presents part of the results from a survey of about 2,500 students from twenty schools in Rio de Janeiro. The results indicate not only the obvious socioeconomic difference between students, but also the presence of cultural elements and of an apparent effect that learning experience may have on students' perspectives and attitudes. Keywords: school prestige, school hierarchies, differences between school classes. 
Nosso problema inicial de pesquisa girava em torno do valor atribuído pelos jovens estudantes do Rio de Janeiro à educação escolar. Tal preocupação foi levantada como base na percepçáo de um aparente esvaziamento de significado do espaço escolar, no sentido de sua definição como instituição historicamente associada aos valores de integraçáo e mobilidade emergentes no decorrer da modernidade organizada (Wagner, 1994), ao menos nas representaçôes de algumas parcelas da população. Na fase inicial da pesquisa, realizamos grupos focais (Costa; Koslinski, 2006) que fortaleceram a hipótese da existência de relativo descenso na valorização associada à educaçáo escolar em meio a parcelas da população urbana cuja experiência de frustração de expectativas vantajosas de inserção na estrutura social foi se acumulando desde o estancamento do desenvolvimento econômico acelerado observado no Brasil, ou seja, aproximadamente desde o início dos anos 80 .

Um survey foi realizado, em seguida, em cerca de vinte escolas do Rio de Janeiro, abrangendo áreas e públicos diferentes da cidade em termos socioeconômicos, bem como sob regimes administrativos distintos. Este artigo apresenta e discute alguns resultados expressivos encontrados nesta segunda fase da investigaçáo, enfatizando a descrição de características da população escolar de nossa cidade, conforme sua distribuição entre escolas e turmas altamente hierarquizadas. Ensaiaremos, também, algumas tentativas de identificar fatores que permitam explicar algumas das diferenças encontradas.

Os resultados obtidos são, como era esperado, expressivos da imensa desigualdade social, manifesta no âmbito do sistema escolar numa grande diferenciação não apenas entre escolas, mas também no agrupamento interno nelas observado. Entretanto, embora tendam a fortalecer a hipótese de que o valor da escola é relacionado às oportunidades que ela proporciona, nossos achados sugerem recusar qualquer determinismo simples emanado das condiçôes econômicas, posto que as variaçóes parecem ser bem condicionadas pelo tipo de experiência/oportunidade escolar vivida.

\section{ENFOQUES DO PROBLEMA}

Recentes discussōes sobre o chamado "efeito-escola" conduzem a atenção para o valor e a capacidade da instituição em alterar previsóes acerca da trajetória escolar e, presumivelmente, social de sua clientela. No auge das discussóes sobre desigualdade social, diante de um quadro em que esta parece não arrefecer, há como um

\footnotetext{
${ }^{2}$ Ver Mortimore et al. (1988), Sorensen e Morgan (2000), Reimers (2000).
} 
revigoramento dos apelos para que as escolas - os sistemas escolares - cumpram papéis destacados em seu enfrentamento. Do ponto de vista específico da sociologia da educação, ao menos a partir dos anos 50, a questão da articulação entre estruturas de oportunidades desiguais e estruturas educacionais tem ocupado o centro de nossas preocupaçóes. No Brasil, estudos recentes, formulados com base nos resultados de desempenho em testes padronizados em escala nacional ou estadual, têm trazido novas luzes para o problema, de maneira geral, retratando as situações de grande insuficiência de nossos sistemas escolares, bem como de sua profunda desigualdade.

Em tais estudos, tem-se fortalecido a impressão - impulsionada pelo uso recente de recursos estatísticos conhecidos como análise multinível, ou modelos hierárquicos - de que elementos coletivos do ambiente escolar, como o padrão de gestáo, ou o perfil do alunado, desempenham papel de destaque na explicaçáo de percursos e rendimentos escolares diferenciados, relativizando a força dos condicionantes socioeconômicos clássicos.

Dessa forma, é razoável propor que haja um efeito-escola, operando para a criação de valores e hábitos entre os estudantes, limitando as influências de seus meios sociais de origem. Talvez isso ajude a explicar porque estudantes de contextos desfavorecidos, quando "deslocados" para espaços escolares freqüentados por estudantes de camadas superiores tendem a desenvolver um desempenho escolar condizente com esse meio. É possível prever a explicação para tal fenômeno que acentue a exposição a recursos escolares "superiores", característicos da desigualdade de oferta educacional; entretanto, não é desprezível uma explicação que ressalte, ao lado dos elementos da oferta institucional, a adaptação a um ethos escolar que maximiza a capacidade de absorção dos recursos escolares, a partir de características culturais desenvolvidas pelos integrados a seu ambiente.

Tal percepção é incorporada ao reconhecimento e rotulagem de um universo de escolas bastante diversificado, por parte de famílias e estudantes em busca de algo que pode ser considerado a melhor oferta escolar, diante das condiçóes de escolha mais ou menos restritas de que dispóem. Na pesquisa norte-americana, em razão de algumas experiências localizadas de diversificação da oferta escolar básica, avolumase uma literatura em torno da denominada "school choice", alimentada por iniciativas como as "charter schools" ou mesmo pela reduzida experiência com vouchers.

Náo é pequena a literatura focada nas aspirações e visóes dos estudantes, suas famílias e meios sociais como fontes de compreensão das diferenças de rendimento e trajetória escolar. Desde as concepçóes inspiradas na vertente teórica que enfatiza os contrastes modernidade/tradição (desenvolvimento/subdesenvolvimento como pro- 
blema prático), as quais emergem com força nos anos 50 do século passado, temos vigorosas correntes de pensamento sociológico que buscam no terreno das atitudes e disposiçóes culturais diante da escola e do sistema escolar as chaves para o desempenho escolar e para os sistemas de estratificação e hierarquização social existentes no mundo moderno. Forquin (1995) ou Karabel e Halsey (1977) resenham ricamente a emergência dessa forma "culturalista" - como diz o primeiro - de abordar o problema, na qual Lipset e Bendix (1959) estão entre os precursores que acentuam os elementos culturais dos meios sociais de origem do estudantado.

Essa discussão, nas décadas de 50 e 60, incluiu trabalhos como os de Clark (1961) e Turner (1961), que mostram a importância de mecanismos que envolvem a competição prolongada ou que "esfriam" as aspiraçóes escolares dos alunos, nos Estados Unidos da América. Esses mecanismos, além de moldarem as aspiraçóes escolares, dado o sistema educacional aberto e competitivo característico da sociedade norte-americana, cumpririam o papel de legitimar o sistema social e evitar revoltas contra este.

A partir da década de 60 , com a crescente radicalização das tendências igualitaristas afluentes desde a Segunda Guerra, novas abordagens e interpretaçôes ganham força no campo da sociologia da educação norte-americana e européia. Essas abordagens passam a considerar a escola como reprodutora de desigualdades: em uma sociedade onde a divisão do trabalho depende não só da propriedade de capital, de títulos e de relaçóes sociais, mas também da educação e de habilidades, as escolas passam a ter importante papel na reprodução e legitimação desta forma moderna de estrutura de classes (Bowles; Gintis, 1977). A escola é vista como reprodutora seja porque reproduz um padrão de cultura de classes de uma geraçáo para outra, além das medidas de capacidade intelectual darem aparência meritocrática que mascaram mecanismos de reprodução (Bowles; Gintis, 1977), seja porque sua principal função é vista como a de ensinar culturas de status (Collins, 1977) seja, ainda, porque a escola tende a reproduzir a estrutura de capital cultural entre as classes e a reforçar as desigualdades sociais iniciais por meio de predisposiçóes internalizadas que resultam na auto-eliminaçáo de classes culturalmente menos favorecidas (Bourdieu, 1977).

Outros estudos, baseados em análises do sistema educacional norte-americano, fogem de explicaçóes que privilegiam fatores relacionados à habilidade, recursos sociais e culturais ou fatores relacionados às classes sociais dos alunos para explicar suas aspiraçóes ocupacionais e educacionais. Por exemplo, Cicourel e Kitsuse (1977) enfocam certas contingências da organização administrativa e decisóes do pessoal das escolas secundárias mediante as quais os objetivos dos alunos são processados. Estes 
apontam que decisóes rotineiras de aconselhamento nestas escolas estão relacionadas à entrada ou não no ensino superior, à escolha de universidades de maior ou menor prestígio e à escolha de carreiras pelos alunos. Já o trabalho de Rist (1977), tomando emprestada a teoria da rotulação (labeling theory), oferece um enquadramento teórico para pesquisas que focalizam mecanismos pelos quais os professores atribuem certas expectativas aos alunos e como estas acabam por ser operacionalizadas dentro da sala de aula - constituindo-se em uma profecia auto-realizada.

Estudos mais recentes realizados nos EUA e no Reino Unido utilizam algumas dessas abordagens para compreender o efeito de práticas de divisão de turmas, tais como o tracking e o ability grouping ${ }^{3}$, sobre as aspiraçóes e escolhas profissionais de alunos de diferentes origens familiares. Esses estudos (Gamorran et al. 1995; Oakes; Guiton, 1995), ao contemplarem o contexto norte-americano, concluem que essas práticas levam ao aumento da desigualdade de performance e contribuem para o aumento da desigualdade entre grupos sociais, uma vez que essas divisóes de turmas coincidem com características socioeconômicas, de raça e de cor.

Entretanto, outro estudo, realizado por Broaded (1997), sugere que esses efeitos podem variar de acordo com o contexto da sociedade mais ampla e com a natureza da institucionalização educacional. $\mathrm{O}$ autor conclui que, ao menos em Taiwan - que apresenta um contexto social menos desigual e uma institucionalização da educaçáo mais homogênea se comparados ao contexto norte-americano - o agrupamento por habilidade e o tracking diminuem a influência da origem social.

Outro estudo que focaliza os efeitos das práticas de tracking é apresentado por Berends (1995). Entretanto, o autor critica trabalhos que ao focarem as atitudes e comportamentos dos alunos, abordam somente algumas das dimensóes do que ele chama de social bonding to school, ou laços sociais com a escola.

Para desenvolver seu conceito central, Berends (op. cit.) se inspira na social bonding theory de Hirschi ${ }^{4}$, usando as dimensóes de vínculo, comprometimento,

${ }^{3} \mathrm{O}$ conceito de tracking geralmente é tratado pela literatura como práticas que levam à escolha de uma trajetória especificamente acadêmica ou vocacional, características de sistemas educacionais duais. Entretanto, os autores que tratam do tracking no contexto norte americano se referem à escolha de disciplinas específicas, no decorrer do ensino secundário, de caráter acadêmico, que são pré-requisitos para entrada no ensino superior, ou de disciplinas mais vocacionais. Já a prática de ability grouping ou agrupamento por habilidade diz respeito à divisão de turmas de uma mesma série de acordo com o desempenho escolar dos alunos.

${ }^{4}$ Travis Hirschi, autor considerado um clássico em estudos de criminologia, desde o final dos anos 60 . 
envolvimento e crença. Assim, em sua análise, o autor toma expectativas educacionais, padróes de assiduidade, problemas de disciplina na escola e engajamento com a escolaridade como constructos para medir o social bonding, ou laços dos alunos em relação à escola.

Os resultados deste estudo apontam que os impactos sobre algumas das dimensôes dos laços sociais em relação à escola podem ser atribuídos às práticas de tracking, mesmo que alguns desses efeitos sejam de tamanho moderado.

Vale ressaltar que, para Berends, expectativas educacionais futuras representam apenas uma das dimensôes de um conceito mais amplo - social bonding to school-e este é o que mais se aproxima das questóes que pretendemos focalizar neste estudo, à medida que o autor procura escrutinar diversas dimensôes que estão relacionadas a uma variação na adesão à instituição escolar.

Com base nesse conjunto diversificado de reflexóes, pretendemos desenvolver aspectos que podem contribuir para sua especificação, chamando a atenção para características diferenciadas do alunado de várias escolas do Rio de Janeiro.

Nossa pesquisa geral, ao tratar do valor atribuído à educação 5 pelos alunos e dos condicionantes a que estariam subordinadas as visóes dos estudantes, abordou elementos clássicos da sociologia da educação, como as expectativas de futuro (escolares e profissionais), e diversos aspectos da vida e das percepçóes desses estudantes. Estas constituem o eixo norteador principal de nossa investigação.

Nessa empreitada, nos deparamos com elementos bastante interessantes, referentes a uma diferenciaçáo entre escolas, manifesta no interior de redes sob dependência administrativa diversa, que se expressa, também, no perfil heterogêneo de sua clientela. Supomos que esse "estilo" diferenciado pode ser interpretado menos pelas características "duras", as variáveis socioeconômicas, que pelo influxo da dimensão cultural.

Pretendemos explorar, com o presente trabalho, a hipótese de que a reputação de uma instituiçáo escolar seja um elemento por si só diferenciador de sua clientela, atuando de forma a "inercialmente" produzir diferenças escolares náo condicionadas a fatores "duros". Além disso, os mecanismos de diferenciação interna, entre turmas

\footnotetext{
${ }^{5}$ Para uma apresentação mais detida dos pressupostos teóricos da pesquisa ver Costa (2001).
} 
escolares, também cumprem papel relevante, pois estão associados às diferenças socioeconômicas e culturais. Pensamos especificamente nas escolas públicas que, por disporem de uma reputação diferenciada em seu entorno geográfico, logram atrair públicos específicos, identificados por seu "estilo" característico. Este seria um elemento que se reproduziria, criando um certo clima escolar tendencialmente afinado com o prestígio da escola.

Nosso ponto de partida foi a realização de grupos focais - não relatados neste trabalho ${ }^{6}$ - com quinze turmas de diferentes escolas da cidade do Rio de Janeiro, que revelaram opinióes bastante diversas dos estudantes acerca de vários aspectos de suas vidas escolares e das expectativas para o futuro, bem como do valor e da finalidade que atribuíam a suas experiências escolares. Tais opiniôes pareciam mais aglutinadas em função do tipo de grupamento escolar (turmas e escolas) freqüentado por tais alunos que por suas condiçóes socioeconômicas.

Posteriormente, com a realização do survey, alguns aspectos puderam ser explorados com a possibilidade de adoção de recursos comparativos mais efetivos. Aqueles tipicamente ligados a valores e opinióes do survey foram, em boa parte, inspirados nos grupos focais realizados com os estudantes. Surgiu nítido questionamento do valor da escola e das possibilidades que esta descortinaria, por parte de alunos integrantes de turmas de baixo prestígio (as turmas "03" e "04") e condiçóes econômicas precárias, as quais não permitiriam prognósticos otimistas, considerando nossos baixos padróes de mobilidade social. No entanto, em condiçóes socioeconômicas equivalentes, nas turmas " 01 ” e em escolas de maior prestígio ${ }^{8}$, opinióes e expectativas eram bem distintas.

Assim informados, e também por uma literatura relativamente recente que procura estudar os jovens no Brasil', partimos a campo de posse de um questionário

${ }^{6}$ Ver Costa e Koslinski, 2006.

${ }^{7}$ Esta é uma denominação caricatural que procura expressar uma das formas mais comuns por meio da qual se pode identificar a estratificação entre turmas no interior das escolas. As de numeraçáo mais elevada, freqüentemente, designam agrupamentos de alunos de menor rendimento escolar e, normalmente, de mais baixo nível socioeconômico.

${ }^{8}$ A informaçáo sobre "prestígio" da escola foi colhida em contatos com os órgãos administrativos das redes públicas ou por conhecimento, no caso das escolas privadas.

${ }^{9}$ Ver o excelente inventário organizado por Spósito (2002). 
razoavelmente extenso e rico em informaçóes, que foi dividido em seis seções. A primeira colhe dados sobre a família dos respondentes, sua estrutura; perfil profissional e educacional dos pais; cor, religiáo e hábitos religiosos dos respondentes; e posse de bens domésticos. A segunda seção contempla informações sobre hábitos e obrigaçôes dos estudantes, bem como sobre os cursos extra-escolares que freqüentam. $\mathrm{Na}$ terceira há perguntas acerca da trajetória escolar e algumas sobre o relacionamento da família com a escola. A quarta seção tenta obter as expectativas de futuro dos jovens da amostra; os fatores que eles associam com as perspectivas de futuro; e comparaçóes com a vida e as oportunidades de seus pais. Por fim, a quinta e última seção versa sobre a avaliaçáo que os estudantes fazem de sua escola e de sua escolarização, com alguma retomada das expectativas de futuro.

Enquanto na rede pública foi possível - e os resultados referendarão esta afirmativa - contar com boa diversidade de escolas, entre as privadas conseguimos acesso a somente três - uma em cada regiáo em que a cidade foi dividida - de prestígio elevado em sua área, e a uma escola situada na zona norte, em uma regiáo bastante pobre. Esta última, apesar de atender a uma clientela de poucos recursos e não gozar de reputação destacada, se comparada às demais, é uma escola atípica, uma vez que possui caráter filantrópico, sendo vinculada a uma igreja evangélica e, provavelmente, prestando serviço de qualidade superior ao que indicaria sua reduzidíssima mensalidade.

Nossa investigação envolveu a aplicação de 2600 questionários a jovens da segunda metade do ensino básico em diversas escolas, procurando atingir turmas que tivessem prestígio no interior das escolas. Os resultados aqui expostos se referem a uma parcela desses questionários (1353), aqueles aplicados às turmas de $6^{\mathrm{a}}$ a $8^{\mathrm{a}}$ séries do ensino fundamental.

\section{ALGUNS RESULTADOS}

A maior parte dos resultados apresentados obedecerá a uma distinção entre escolas e turmas. As escolas constantes da amostra estáo diferenciadas pela dependência administrativa ( $\mathrm{M}$ - municipal e $\mathrm{P}$ - privada), pela área da cidade em que se encontram ( $\mathrm{S}$ - Sul, T - Tijuca e adjacências, $\mathrm{N}$ - Norte e $\mathrm{O}$ - Oeste), e pela reputação que possuem (+ ou -) colhida, informalmente, com base em informaçóes da própria Secretaria de Educação (escolas municipais) ou pela impressão de estudantes universitários residentes em suas proximidades (escolas privadas). Dessa forma, o sistema de identificação das escolas é composto por uma seqüência de três caracteres que indicam, respectivamente, a dependência administrativa, a área geográfica e o 
prestígio imputado $^{10}$. A distinção entre as áreas da cidade obedece a uma certa hierarquia socioeconômica, expressa na valorização imobiliária das regióes, que pode, grosso modo, ser considerada descendente no sentido (Sul-Tijuca-Norte-Oeste).

Ainda que diversificada, a amostra estudada não deve ser considerada representativa do universo de escolas da cidade do Rio de Janeiro, composto por mais de mil unidades escolares públicas e centenas de escolas privadas. Assim, os resultados devem ser tomados estritamente como referentes aos ambientes pesquisados.

Nossa amostra ficou composta (no caso dos dados aqui expostos, das séries finais do ensino fundamental, em turno diurno) por duas escolas municipais e uma privada em cada área geográfica. Apenas na zona norte logramos aplicar o questionário a uma escola privada cuja reputação náo poderia ser considerada elevada, para os padróes locais. Situada nas bordas de uma favela e atendendo a uma população residente majoritariamente nesse local, tal escola, de caráter filantrópico - vinculada a uma instituição evangélica -, destoa bastante das demais escolas particulares que permitiram a realização de nossa pesquisa. Ainda que cobre mensalidades, mas de baixo valor, esta não é uma característica da maioria das escolas privadas que atendem a larga parcela da classe média baixa, no Rio de Janeiro.

Outra escola que pode ser considerada atípica, na rede municipal é a $\mathrm{MO}+(\mathrm{mu}-$ nicipal da zona oeste, com alto prestígio). Conforme se observará, trata-se de uma escola que atende a um público de nível socioeconômico bem baixo e alta defasagem idade/série dos alunos. Seu diferencial é que se localiza numa área semi-rural - algo bastante raro no Rio de Janeiro - talvez no ponto mais distante do centro da cidade (mais de $70 \mathrm{~km}$ ).

Para uma abordagem de conjunto que permita visualizar as diferenças intra e entre escolas, as turmas foram divididas quanto ao seu suposto prestígio no interior das unidades escolares, reconhecendo a prática comum adotada nas escolas públicas de organizar as turmas com base nas idades de seus integrantes ${ }^{11}$. Para tal, a medida da idade média observada na série, no conjunto da amostra, foi considerada o ponto

${ }^{10}$ Apenas na zona sul, a área mais valorizada da cidade, parece ter havido uma identificação pouco clara das escolas municipais quanto a seu prestígio.

${ }^{11} \mathrm{Na}$ verdade, entrevistas com as direçóes nos permitiram constatar que o critério real de distribuição de alunos entre as turmas é o rendimento escolar. Havíamos observado alunos com defasagem idade/série, mas não por motivos de rendimento escolar, encaixados em turmas compostas por alunos com idade correta para a série. Este seria um recurso que as direçóes escolares utilizam para "proteger" alunos, de bom rendimento e comportamento disciplinar adequado, da inclusáo em turmas de baixo rendimento. 
de corte entre turmas que denominamos de alto e baixo prestígio, o que deve ser considerado efetivo apenas nas escolas municipais.

Dada a dificuldade em colher informações, especialmente com um público predominantemente jovem e sem responsabilidades econômicas em suas residências, que permitam caracterizar com precisão o nível socioeconômico dos estudantes pesquisados, optamos por recorrer a uma variável indicativa dessa dimensão, composta por uma escala de posse de bens domésticos, pela escolaridade dos pais, pela ocupação dos pais e pela diversidade de oportunidades de uso de computador ${ }^{12}$.

O gráfico 1 mostra como as diferenças socioeconômicas se associam com essa hierarquização intra e extra-escolar:

Gráfico 1 - Nível socioeconômico médio (Z), por escola

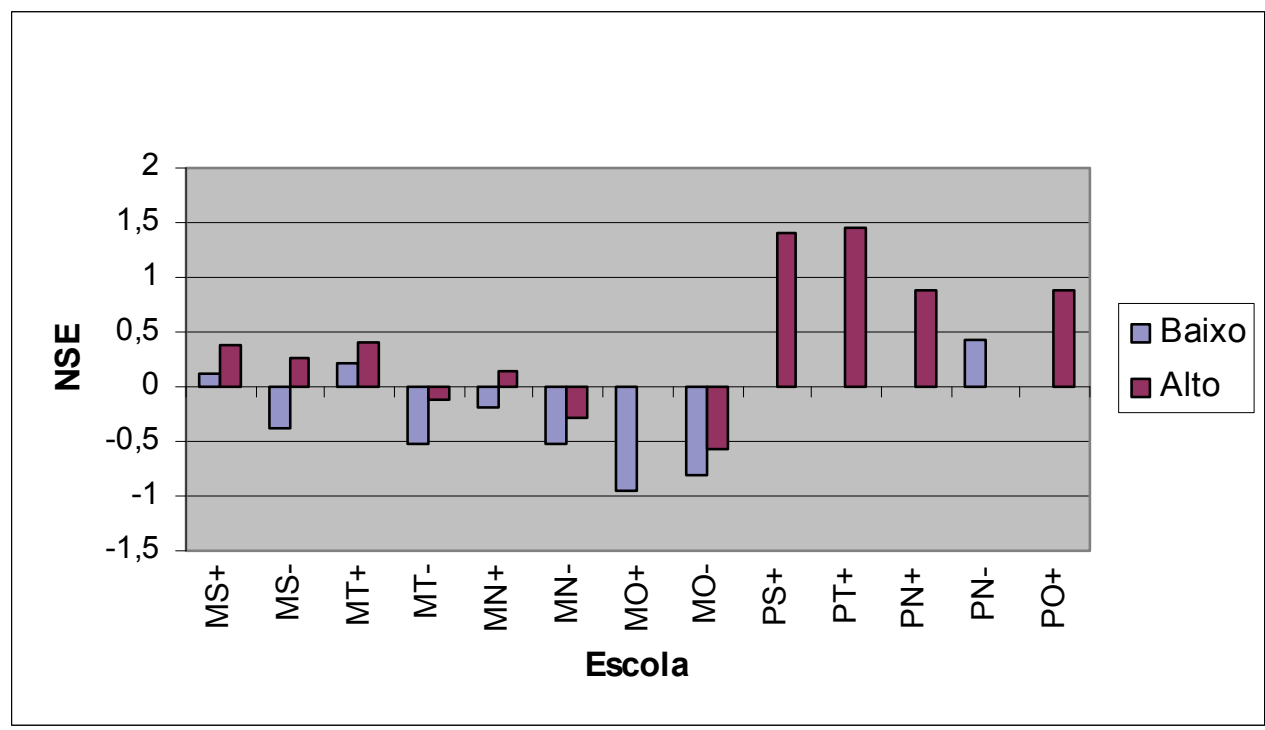

A média do score de condição socioeconômica, segundo as escolas e a distribuição interna de turmas, revela clara diferença entre as particulares e as públicas, e, além disso, uma vantagem para as escolas mais próximas da região centro-sul da cidade. Internamente, porém, nas escolas municipais, as turmas com maior defasa-

${ }^{12} \mathrm{O}$ procedimento adotado consistiu em somar essas variáveis padronizadas, padronizando-se também a nova variável gerada. 
gem idade/série estão em um patamar socioeconômico inferior, conforme mensurado. Em alguns casos, a distância é considerável, como na escola MS-.

Essa medida da defasagem idade/série pode ser considerada uma síntese da trajetória escolar, marcada não só pelas desigualdades econômicas, mas também por oportunidades sociais e por outros fatores presumíveis, entre eles a própria experiência escolar pregressa. O gráfico 2 apresenta a distribuição da medida de defasagem, em anos, por escola.

Gráfico 2 - Defasagem média (anos), por escola

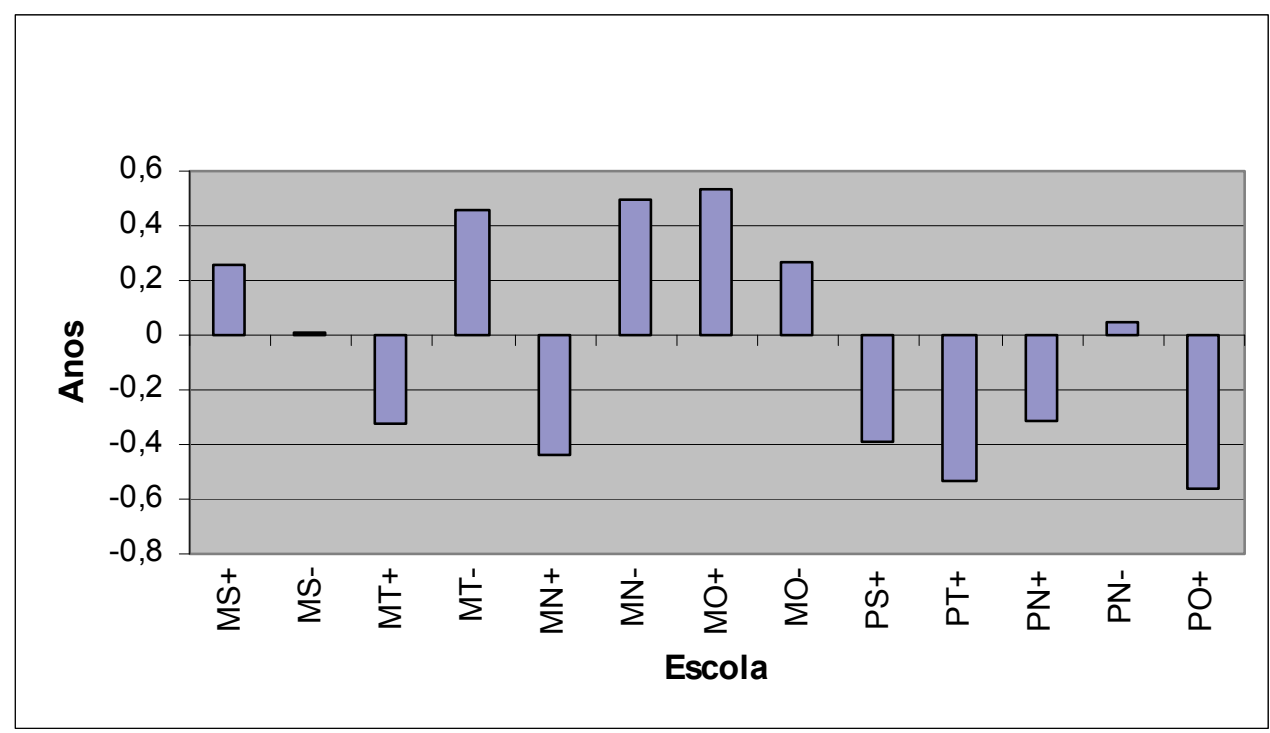

Exceto na escola semi-rural da zona oeste $(\mathrm{MO}+)$ e na escola de melhor prestígio da zona sul $\left(\mathrm{MS}_{+}\right)^{13}$, a defasagem fica inferior à média, nas escolas de prestígio mais elevado (+). Há, no entanto, especificamente nessas escolas da zona sul, um fenômeno interessante: sua diferenciação quanto aos aspectos culturais, como será demonstrado mais adiante.

A defasagem, medida de forma padronizada, nas duas escolas de maior prestígio da rede municipal (MT+ e $\mathrm{MN}+$ ), mesmo nas turmas cuja média de idade dos alunos está acima da média geral observada para a série (turmas de "baixo prestí-

${ }^{13}$ Conforme informado, a diferença entre as escolas da zona sul não aparece nitidamente. 
gio"), é bem inferior à das demais turmas em condiçôes equivalentes, nas outras escolas (Gráfico 3).

Gráfico 3 - Defasagem Média (anos), por Escola, segundo o Prestígio da Turma

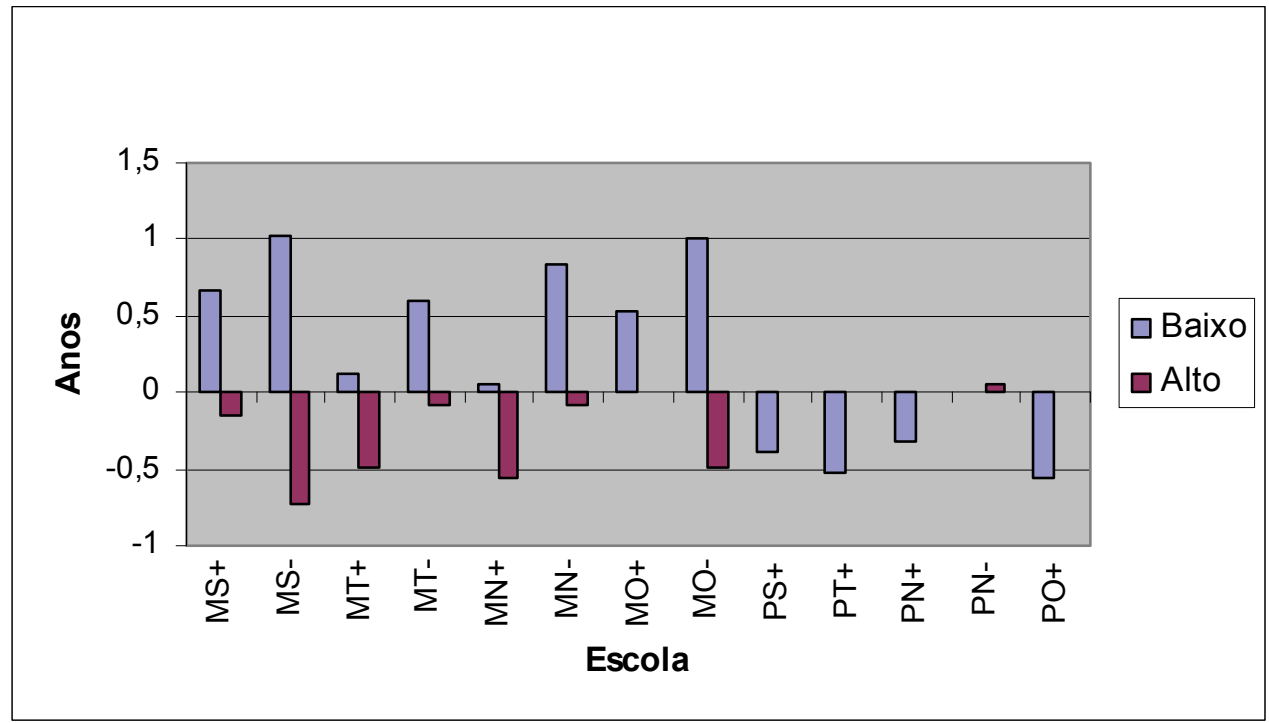

Há, portanto, clara diferenciação socioeconômica e de trajetória escolar entre as escolas e as turmas no interior das escolas - municipais. Ainda que o coeficiente de correlação (Pearson) entre a defasagem idade/série e as condiçóes socioeconômicas seja moderado $(r=0,30)$, essa diferenciação parece também sofrer a influência de outros princípios, como a localização geográfica na cidade. Por exemplo, as diferenças de cor da pele (autodeclarada) são relevantes entre as escolas ${ }^{14}$, mas não há diferenças significativas entre brancos e não brancos na distribuição das turmas no interior das escolas. No entanto, a distribuição por sexo é mais relevante (Tabela 1). Com uma exceção (MN-), todas as turmas de mais alto prestígio (menor defasagem idade/série), nas escolas municipais, possuem maior porcentual feminino em sua composição. O mesmo ocorre nas escolas privadas, conforme elas se aproximam dos estratos socioeconômicos mais baixos e das áreas menos valorizadas $(\mathrm{PN}+, \mathrm{PN}-\mathrm{e} \mathrm{PO}+)$.

${ }^{14} \mathrm{Na}$ mesma área geográfica, as escolas de menor prestígio sempre têm um porcentual menor de alunos que se declaram brancos. Este porcentual também se reduz à medida que vamos nos afastando das áreas mais valorizadas da cidade. 
Tabela 1 - Distribuição do número de alunos por sexo, segundo o prestígio da turma e a escola

\begin{tabular}{ll|c|c}
\hline \multirow{2}{*}{ Escola } & \multirow{2}{*}{ Prestígio da turma } & \multicolumn{2}{|c}{ Sexo } \\
\cline { 2 - 4 } & & Masculino & Feminino \\
\cline { 2 - 4 } MS+ & Baixo & 54,0 & 46,0 \\
\hline \multirow{2}{*}{ MS- } & Alto & 43,8 & 56,3 \\
\cline { 2 - 4 } & Baixo & 56,9 & 43,1 \\
\hline \multirow{2}{*}{ MT+ } & Alto & 42,0 & 58,0 \\
\hline \multirow{2}{*}{ MT- } & Baixo & 63,3 & 36,7 \\
\hline \multirow{2}{*}{ MN+ } & Alto & 46,3 & 53,7 \\
\cline { 2 - 4 } & Baixo & 51,5 & 48,5 \\
\hline \multirow{2}{*}{ MN- } & Alto & 33,3 & 66,7 \\
\hline \multirow{2}{*}{ MO+ } & Baixo & 53,1 & 46,9 \\
\hline \multirow{2}{*}{ MO- } & Alto & 45,2 & 54,8 \\
\cline { 2 - 4 } & Baixo & 49,3 & 50,7 \\
\hline PS+ & Alto & 62,8 & 37,2 \\
\hline PT+ & Baixo & 48,5 & 51,5 \\
\hline PN+ & Baixo & 53,1 & 46,9 \\
\hline PN- & Alto & 51,2 & 48,8 \\
\hline PO+ & Alto & 50,0 & 50,0 \\
\hline
\end{tabular}

Para descrever os estudantes pesquisados em termos de seus hábitos, valores e expectativas, recorremos principalmente à análise fatorial. Por meio de diversas perguntas, que tentavam identificar com que freqüência determinadas práticas eram realizadas, que valores eram afirmados e quais as expectativas dos jovens com relação ao futuro, procuramos traçar seus perfis e observar como eles se distribuem pelas escolas e turmas analisadas. Como previmos, a tarefa não foi fácil, dada a grande diversidade de situaçóes no universo da pesquisa.

O questionário continha diversas perguntas sobre a freqüência com que os jovens consultados realizam as seguintes atividades: ir ao cinema, ao teatro, a festas ou bailes, a shows, à praia, a parques ou passeios, ouvir rádio, assistir a TV, ajudar nas tarefas de casa, praticar esportes, reunir-se com os amigos, fazer tarefas escolares e ler, freqüentar o templo. 
A análise fatorial é um procedimento estatístico que busca reduzir uma multiplicidade de variáveis a dimensóes inteligíveis. Por meio desse recurso, procuramos identificar afinidades entre as informaçóes prestadas a respeito das práticas sociais dos jovens, construindo indicadores que caracterizavam perfis de comportamentos.

Após várias tentativas de identificação de elementos comuns, a solução mais recomendável nos pareceu a de seguir indicações emanadas da seguinte análise fatorial (Tabela 2):

Tabela 2 - Matriz de componentes - hábitos e costumes*

\begin{tabular}{l|r|r|r|r}
\hline & \multicolumn{4}{|c}{ Componentes } \\
\cline { 2 - 5 } & \multicolumn{1}{|c|}{$\mathbf{1}$} & \multicolumn{1}{|c}{$\mathbf{2}$} & \multicolumn{1}{l}{$\mathbf{3}$} & \multicolumn{1}{c}{$\mathbf{4}$} \\
\hline Freqüência - cinema & 0,619 & $-0,212$ & $-0,279$ & 0,361 \\
Freqüência - teatro & 0,479 & 0,028 & $-0,585$ & $-0,055$ \\
Freqüência - shows & 0,729 & $-0,112$ & 0,002 & $-0,165$ \\
Freqüência - rádio & 0,388 & 0,281 & 0,542 & $-0,062$ \\
Freqüência - TV & 0,248 & 0,245 & 0,497 & 0,609 \\
Freqüência - festas/bailes & 0,725 & $-0,090$ & 0,172 & $-0,073$ \\
Freqüência - ajuda nas tarefas & 0,026 & 0,598 & 0,171 & $-0,560$ \\
de casa & & & & \\
Freqüência - reúne-se com & 0,508 & $-0,144$ & 0,139 & $-0,031$ \\
amigos & 0,540 & $-0,097$ & 0,012 & $-0,316$ \\
Freqüência - vai à praia & 0,150 & 0,693 & $-0,214$ & 0,230 \\
Freqüência - tarefas & 0,158 & 0,642 & $-0,364$ & 0,095 \\
\hline escolares/estudar & & &
\end{tabular}

Método de extração: principal componente.

* Número de componentes extraídos: 4.

Com base nessa análise, a decisão foi por trabalhar inicialmente com as duas primeiras dimensóes extraídas. A primeira - e mais clara - aglutina as variáveis referentes a atividades externas e de lazer (cinema, shows, teatro, festas/bailes, praia, reunir-se com amigos). Essa dimensão foi denominada "balada". A segunda dimensão mostra uma afinidade nítida entre cumprir as tarefas escolares/estudar e ler, além de "ajudar nas tarefas de casa". Para essa dimensão usamos a designação "estudo/leitura"

${ }^{15}$ Ainda que forneça pistas importantes para análise e dimensóes sociologicamente coerentes, nesse caso, a análise fatorial não foi utilizada diretamente na geração de variáveis decorrentes 
Uma distribuição desses hábitos e práticas é apresentada nos gráficos 4 e 5 .

Gráfico 4 - Atividades de lazer ("balada"), por escola, segundo o prestígio da turma

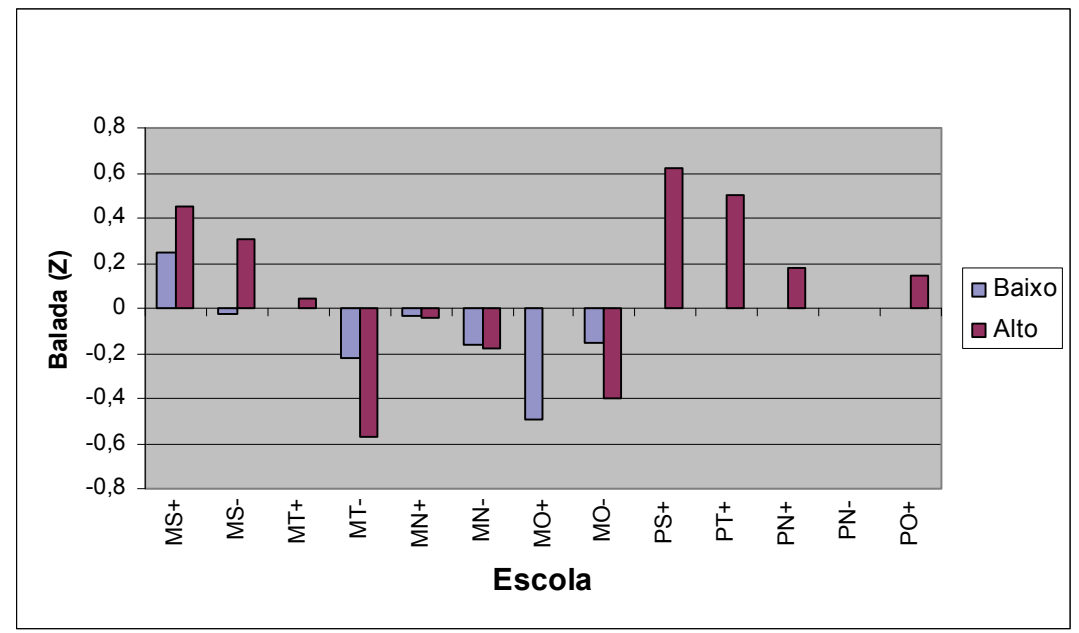

Gráfico 5 - Hábitos de estudo, por escola, segundo o prestígio da turma

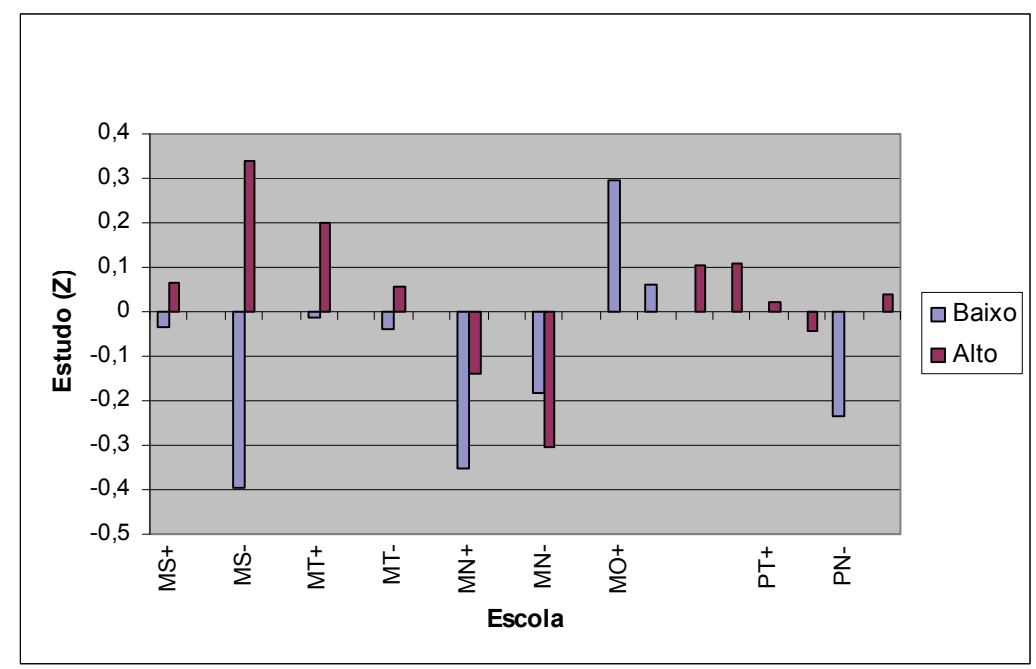

dos fatores, por força de Eigenvalues relativamente baixos, exceto no caso do primeiro fator $(2,48)$, e, sobretudo, em razão de algumas variáveis saturarem, com carga razoável, mais de um fator. Assim, a solução escolhida foi utilizar as "sugestōes" provindas das dimensóes obtidas na análise fatorial, mas trabalhar diretamente com variáveis compostas pelo somatório daquelas que parecem constituir dimensôes coerentes, devidamente padronizadas, ou individualmente com as variáveis que, de forma menos nítida, se associam com outras. Na segunda dimensão, por ora, foi excluída a variável indicativa da freqüência com que os estudantes "ajudam nas tarefas de casa”, por confundir a análise em termos socioeconômicos. 
A prática de atividades recreativas obedece nitidamente a uma ordem que acompanha a distribuição geográfica e socioeconômica da cidade. Assim, da zona sul à zona oeste e das condiçốes socioeconômicas mais vantajosas às menos vantajosas, decresce o hábito desse tipo de lazer. Evidentemente, a oferta desigual de serviços urbanos pode ser responsável por uma parcela desse resultado. É interessante notar, além disso, que enquanto nas escolas públicas da zona sul as turmas de melhor prestígio declaram praticar mais esse tipo de atividade, nas demais áreas a situação se inverte, sugerindo que nas camadas mais pobres a trajetória escolar mais "limpa" deve estar associada a comportamentos mais reclusos e menor convívio social.

Já os hábitos de estudo/leitura (mais uma vez com exceção da escola MN-) distinguem claramente, como previsto, as turmas de maior e menor prestígio. Nas escolas que atendem a população de melhor nível socioeconômico é relativamente baixa a freqüência com que os jovens relatam essas atividades; no entanto, isso pode ocorrer, em razão da comparação feita pelos pesquisados, decorrente das diferentes atividades que realizam.

A avaliação geral que os estudantes fizeram das escolas ${ }^{16}$ acompanha, praticamente, a reputação prévia de que dispúnhamos (Gráfico 6).

Gráfico 6 - Avaliação geral da escola, segundo o prestígio da turma

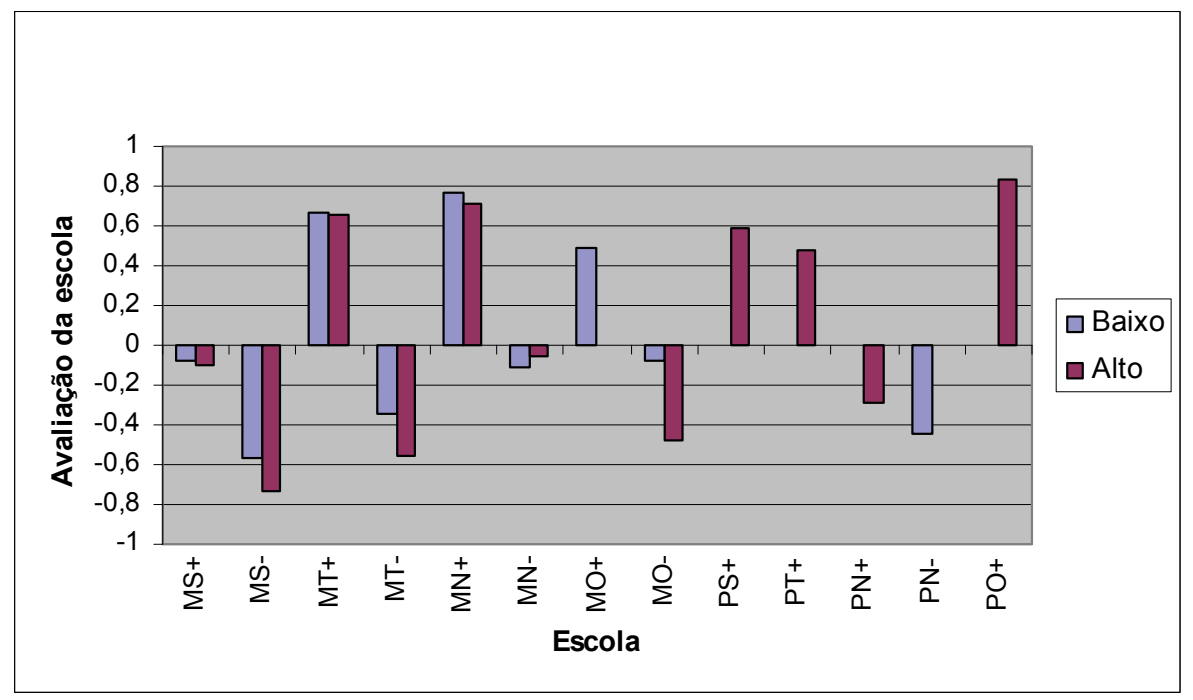

${ }^{16}$ Escalas de satisfação foram preenchidas pelos estudantes acerca de vários aspectos das escolas, como beleza, organização, disciplina, limpeza, qualidade do ensino, etc. 
Note-se que não há, na mesma escola, situações de avaliaçôes polares entre as turmas de diferente prestígio, e que as mais conceituadas costumam ser mais críticas com relação a esse aspecto.

Desta dimensão - avaliação da escola - passamos a outra, na tentativa direta de identificar o valor que os estudantes atribuem à educação.

O gráfico 7 mostra a nota atribuída (de 1 a 10 ) pelos estudantes para a importância da escola em suas vidas.

Gráfico 7 - Importância da escola na vida dos alunos, segundo o prestígio da turma

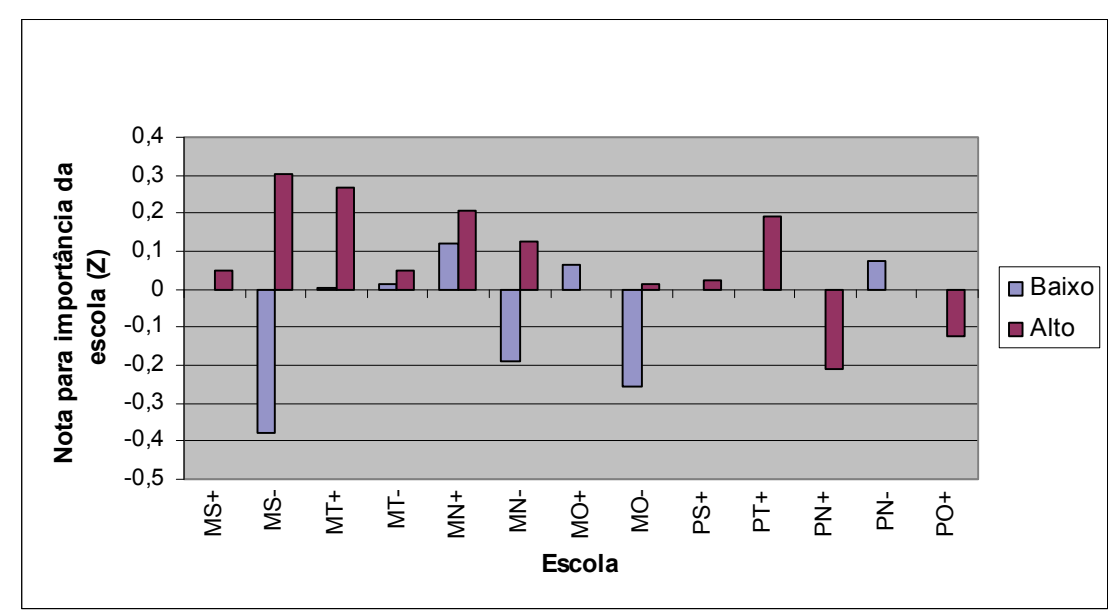

Como se observa, há contrastes importantes, sempre desfavoráveis às turmas de menor prestígio. Em média, também os estudantes das escolas privadas tendem a declarar uma importância relativamente mais baixa da escola em suas vidas, que poderia ser tomada como a medida do valor atribuído à educação, conforme a discussão original da pesquisa. Entretanto, a elevada pontuação média dessa variável, sua pequena dispersão, e, sobretudo, o fato de talvez encontrarmos para essa pergunta respostas que seriam as esperadas pelos pesquisadores, resolvemos buscar em outros indicadores mais próximos das expectativas de escolarização futura uma medida alternativa para aferir o valor da escola. $\mathrm{O}$ gráfico 8 expressa a distribuição dessa variável, composta pela soma dos valores padronizados das variáveis ordinais que indicam o que os estudantes pensam estar fazendo daqui a dois anos e daqui a $\mathrm{dez}^{17}$, até que série escolar pensam que vão estudar e o nível de escolaridade mínima requerido pela profissão que esperam ocupar quando adultos.

${ }^{17} 1$ - Somente estudando; 2 - Estudando e trabalhando; 3 - Somente estudando. 
Gráfico 8 - Expectativas de escolarização futura, segundo o prestígio da escola

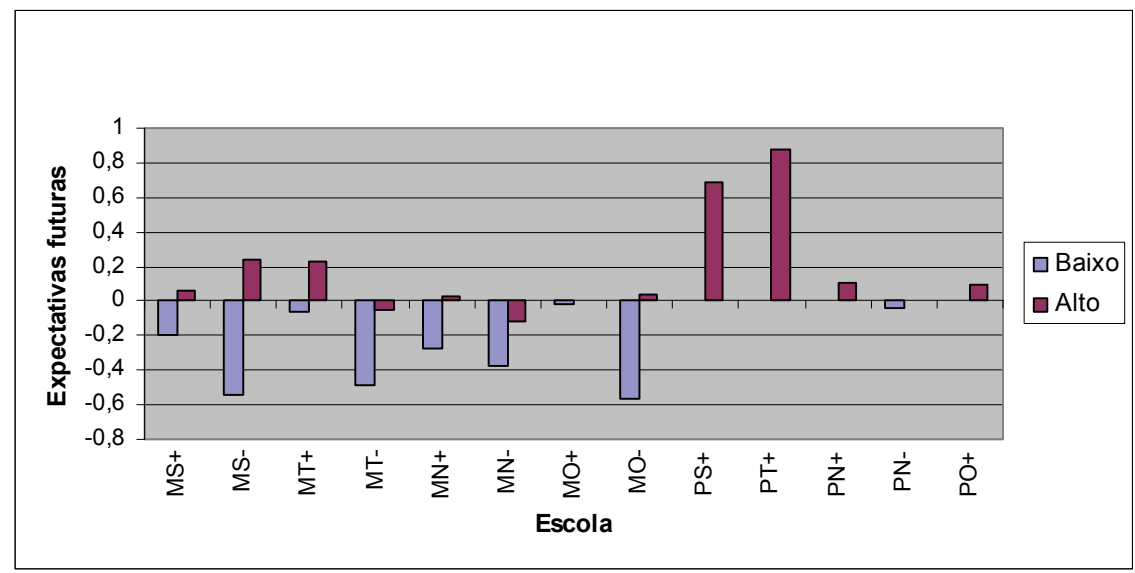

Do nosso ponto de vista, esta segunda forma de mensurar, uma vez que remete a posiçôes futuras almejadas/vislumbradas pelos estudantes, expressaria, talvez com mais acuidade, o valor e o significado conferido à educação escolar. O contraste fica nítido entre as escolas típicas "de classe média” e as demais, mas também é marcante entre as turmas de padróes escolares distintos. De certa forma, um certo ar "blasé", que recusa atribuir um alto valor à educaçáo escolar, encontrado entre numerosos estudantes de classe média, se desfaz quando colocados diante de suas perspectivas reais de futuro.

No entanto, ele como que retorna, quando os entrevistados se deparam com opçóes de elementos importantes para suas vidas futuras. Convidados a atribuir notas de 1 a 10 a cada um dos fatores mencionados na tabela 3, os resultados puderam ser nitidamente agrupados, por meio de análise fatorial.

Tabela 3 - Matriz de componentes (rotacionada)

\begin{tabular}{l|c|c}
\hline \multirow{2}{*}{} & \multicolumn{2}{|c}{ Componentes } \\
\cline { 2 - 3 } & $\mathbf{1}$ & $\mathbf{2}$ \\
\hline Estudar muito & 0,070 & 0,821 \\
Trabalhar duro & 0,048 & 0,821 \\
Dar sorte & 0,689 & 0,018 \\
Conhecer as pessoas certas & 0,677 & 0,166 \\
Ter boas condições financeiras & 0,756 & 0,039 \\
Boa aparência & 0,732 & 0,002 \\
\hline
\end{tabular}

Método de extração: componente principal.

Método de rotação: Varimax com Kaiser Normalization. 
Com relação aos itens acima ${ }^{18}$, há nítida distinção entre duas visões para estabelecimento de um futuro almejado. Na primeira, a afinidade se estabelece entre elementos adscritos e casuais: "dar sorte", "conhecer as pessoas certas", "ter boas condiçôes financeiras" e "boa aparência”. Denominamos essa dimensão "fatores fortuitos". A segunda, igualmente clara, mostra a tendência a pontuaçóes com alta correlação entre "estudar muito" e "trabalhar duro", configurando uma visão de mundo próxima das noções de esforço, desempenho e conquista; dimensão que podemos denominar "fatores meritocráticos".

A distribuição dessas duas dimensões entre as turmas e escolas é apresentada nos gráficos 9 e 10 .

Gráfico 9 - Fatores meritocráticos por escola, segundo o prestígio da turma

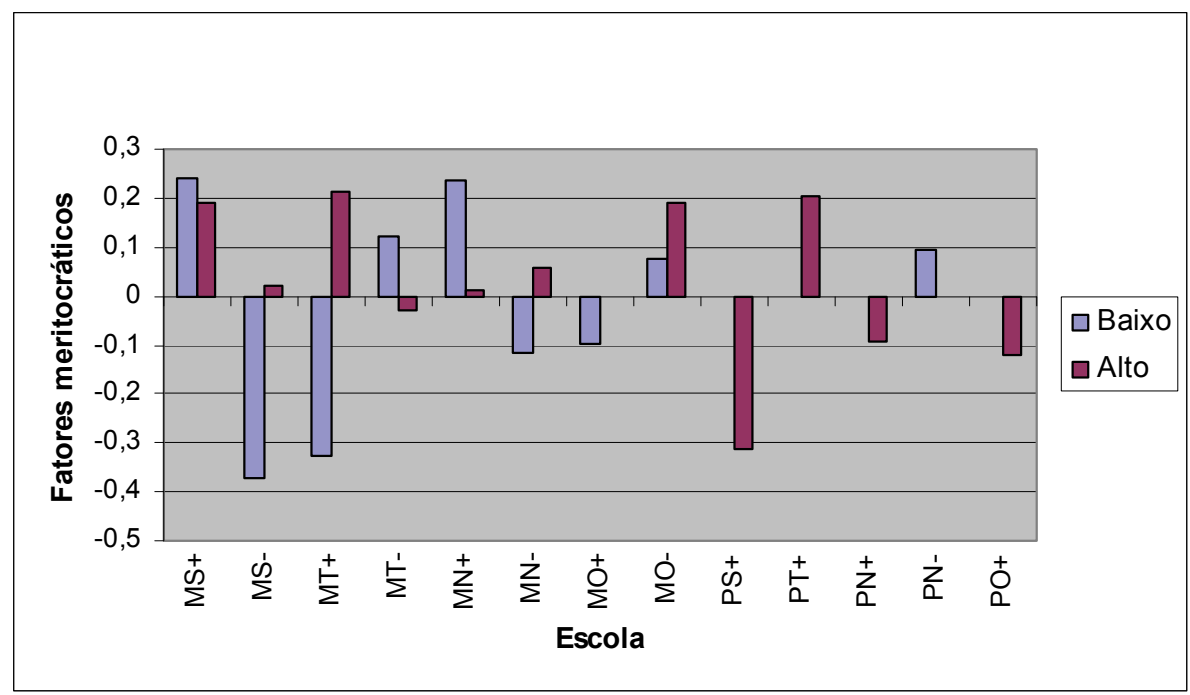

Os "fatores meritocráticos" distinguem razoavelmente as turmas mais ou menos prestigiadas, alinhando, como pouco afeitas a tal dimensão, a maioria das escolas tipicamente particulares e as turmas de baixo prestígio das escolas públicas ${ }^{19}$.

\footnotetext{
${ }^{18}$ Havia mais um item - "fazer cursinhos" - que não se mostrou discriminante suficiente para integrar a análise.

${ }^{19}$ Esses resultados demandariam uma discussão detalhada e bem específica referente a estilos, como, por exemplo, um certo aspecto aristocrático da escola mais "rica" da amostra (PS+)
} 
Gráfico 10 - Fatores fortuitos por escola, segundo o prestígio da turma

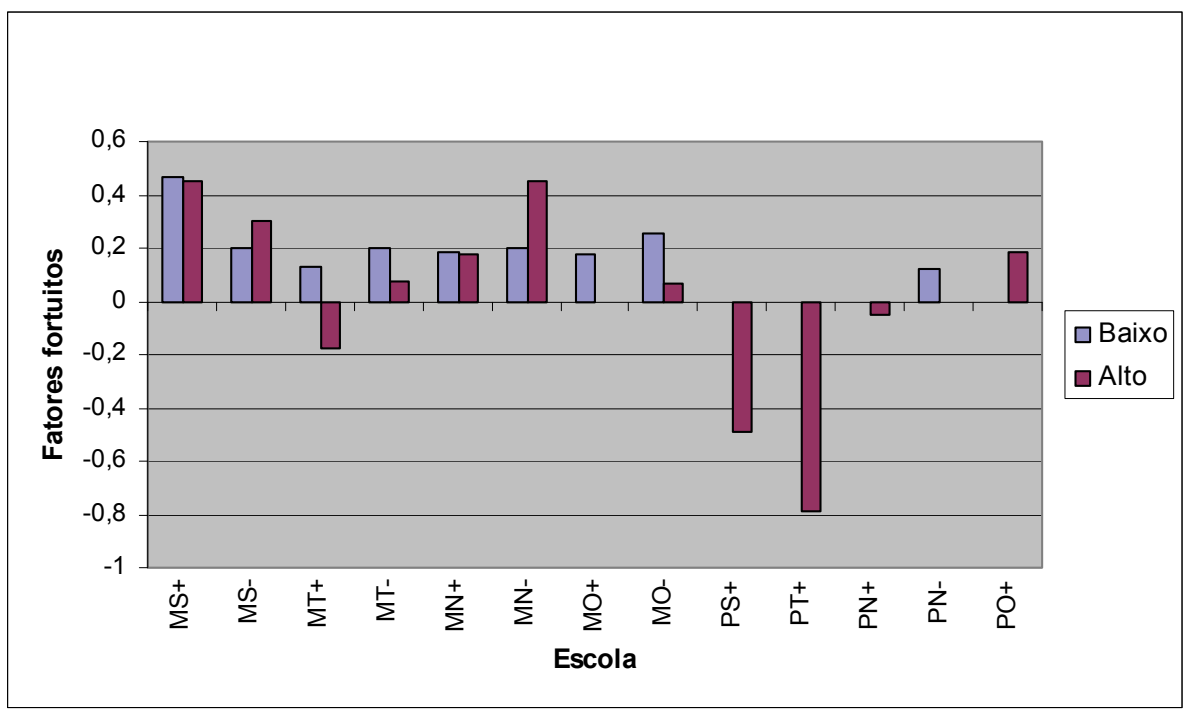

Por outro lado, a dimensão "fatores fortuitos" distingue nitidamente os que são claramente avessos aos caracteres adscritos e ocasionais diante das definiçóes de perspectivas futuras de vida. Parece haver certa incoerência entre esses achados e a declaração direta do valor atribuído à educação escolar pelos estudantes em algumas escolas e turmas - algo que pretendemos explorar melhor em outros momentos deste estudo.

Por fim, procurando compreender os elementos que estariam casualmente associados à definição deste valor da educação entre os estudantes pesquisados, buscamos o recurso da regressão linear múltipla.

A tabela 4 apresenta os coeficientes obtidos no modelo que melhor conseguiu explicar a nota atribuída pelos estudantes à importância da escola em suas vidas. Conforme já assinalado, a variável dependente não apresenta grande amplitude e variância, mas, ainda assim, suas variaçóes parecem associadas predominantemente a aspectos tipicamente atitudinais ou culturais, fracamente associados a variáveis "duras", socioeconômicas.

Apenas a variável "tem amigos que já pararam de estudar" pode ser considerada a característica mais próxima do que se poderia denominar "estrutural", indicando o meio de convivência dos alunos, exercendo algum poder preditivo sobre essa variável dependente, ainda que com coeficiente padronizado entre os mais baixos.

Continuando a análise, um modelo mais rico e que depende menos das variáveis acima foi gerado para tentar explicar o valor da educação expresso na forma de 
Tabela 4 - Coeficientes de regressão*

\begin{tabular}{l|r|r|c}
\hline \multicolumn{1}{c|}{ Modelo } & \multicolumn{1}{c|}{ B } & \multicolumn{1}{c|}{ Beta } & \multicolumn{1}{c}{ Sig. } \\
\hline 1 (Constante) & 6,644 & & 0,000 \\
Fatores meritocráticos & 0,341 & 0,243 & 0,000 \\
Se considera um aluno: & 0,315 & 0,173 & 0,000 \\
Gosta da escola? & 0,221 & 0,150 & 0,000 \\
Pais iam à escola & 0,110 & 0,087 & 0,001 \\
Até que série pensa que vai & 0,106 & 0,067 & 0,011 \\
estudar & $-0,195$ & $-0,061$ & 0,020 \\
Repetiu alguma série & 0,169 & 0,054 & 0,033 \\
Já escolheu a profissão? & $-0,049$ & $-0,052$ & 0,050 \\
Tem amigos que pararam de & & \\
estudar?
\end{tabular}

* Variável dependente: nota para importância da escola na vida: $\mathrm{R}^{2}=0,20$

expectativas de escolarização futura (Gráfico 8), tomando, então, a variável criada para indicá-las como dependente. Dessa feita, a utilização da análise de trajetória (path analysis) mostrou-se a melhor alternativa, por meio da qual os coeficientes de regressão padronizados $(\beta)$ significativos ${ }^{20}$ encontrados estáo expressos de forma esquemática a seguir. $\mathrm{O}$ recurso da análise de trajetória permite mensurar efeitos diretos e indiretos de variáveis que estejam logicamente associadas com o que se pretende explicar. Assim, verificamos que a defasagem idade/série representa o maior condicionante identificado no modelo para as expectativas futuras, embora controlada por fatores altamente "estruturantes", como as condiçôes socioeconômicas e o sexo. Uma vez que essa defasagem pode ser considerada independente em relação à expectativa futura, mas dependente com relação a outras variáveis incluídas no modelo, foi escolhida para ocupar posição intermediária.

O pertencimento a uma família biparental, a intensidade declarada na freqüência a templos religiosos e a regiáo da cidade em que a escola se localiza ${ }^{21}$ apresentaram associação modesta e indireta com as expectativas futuras de escolarização. $\mathrm{O}$ nível socioeconômico, o sexo feminino, o prestígio da escola (alto $=1$ ), ter amigos que pararam de estudar ( 1 = nenhum; 2 = poucos; 3 = alguns; 4 = muitos $)$ e a va-

${ }^{20} \mathrm{p}<0,05$

${ }^{21}$ Variável ordinal que segue uma escala atribuída, descendente, de condições socioeconômicas (Sul-Tijuca-Norte-Oeste). 
riável composta para indicar hábitos de estudo resultaram em associações diretas e indiretas com a dimensão a ser explicada. Já o tamanho da família e uma visão mais meritocrática do futuro (extraída em análise fatorial anteriormente exposta) não guardaram relaçóes significativas com a defasagem escolar, mas mostraram alguma relação direta com as expectativas escolares futuras.

O peso da defasagem escolar é algo a ser detidamente analisado. Essa variável é a síntese de uma trajetória escolar na qual se consubstanciam condicionantes sociológicos e de outras ordens. No entanto, deve ser considerado que, em um modelo multivariado como esse, o fato de o efeito líquido dessa variável ser maior que o do nível socioeconômico chama a atençáo para aspectos intra-escolares - a experiência escolar pregressa dos estudantes - como condicionante mais forte de sua expectativa futura. Ou seja, parece que a dinâmica interna na vida escolar, acima de outros fatores, delineia a trajetória posterior, ao menos no que se refere à auto-expectativa dos estudantes. É necessário, porém, ter cautela ao destacar a defasagem, pois parece frágil tomá-la como o problema escolar em si, como o fazem algumas abordagens. Pensamos na defasagem como decorrência de um conjunto complexo de fatores sociais e escolares.

Quadro 1 - Análise de trajetória para valor da educação

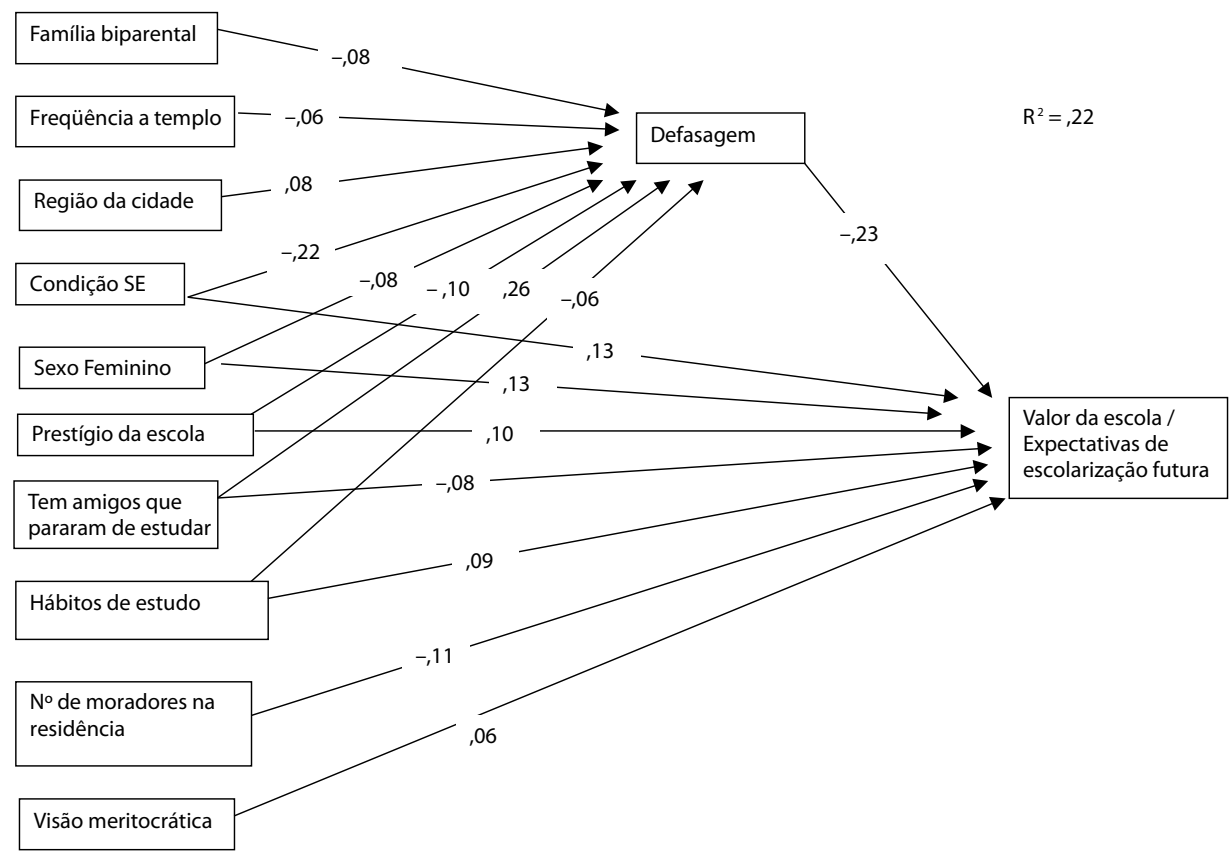


Destaca-se, também, a força da variável "ter amigos que pararam de estudar". Ela deve indicar o ambiente de convivência com pares, dos estudantes. Sua relação com a defasagem é até um pouco superior à do NSE; sugere que os ambientes sociais influenciam bastante nos aspectos estudados, independentemente das condiçóes econômicas. Aspectos atitudinais (visão meritocrática e hábitos de estudo) "sobrevivem" com alguma capacidade explicativa, apontando para dimensôes individuais ou culturais não contempladas.

A condição feminina é um elemento que se destaca, tanto na redução provável da defasagem escolar quanto na ampliaçáo das expectativas escolares futuras, indo na mesma direção que o nível socioeconômico e o prestígio da escola. Esse, porém, é fator independente que, ao preservar o nível de significância, após controle, sugere a força do estabelecimento escolar.

\section{CONCLUSÃO}

Observamos que as expectativas de escolarização variam entre as escolas, assim como entre as turmas de diferente prestígio dentro de uma mesma escola, e, concomitantemente, que elas recebem alunos de perfis socioeconômicos diferenciados. Em nosso último modelo, que pretendeu explicar as aspiraçóes escolares dos alunos, verificamos que a variável explicativa mais forte é a defasagem escolar. É importante notar que esse fator se sobrepóe à alocação em turmas de menor ou maior prestígio, posto que é o critério de enturmação usado nas escolas públicas do Rio de Janeiro.

Em suma, as variáveis "duras" confirmam o que já é apontado na literatura nacional e internacional: há forte hierarquização nas redes escolares, oriunda de sólidos mecanismos seletivos, associados à desigualdade social mais abrangente. Essa hierarquização não se limita às diferenças entre as escolas das redes pública e privada, mas se estende àquelas de diferente prestígio da rede municipal e, em alguns casos, às turmas de uma mesma escola.

Para além da diferença, segundo princípios de hierarquia social ligados às condiçóes econômicas dos alunos, emerge uma rica diferenciação quanto aos elementos dos ambientes culturais desses alunos, em acréscimo às desigualdades que podem ser produzidas no âmbito do próprio processo escolar, materializadas na força que componentes mais estritamente escolares apresentaram na análise.

Esses resultados sugerem futuras investigaçóes acerca do funcionamento desses mecanismos seletivos que operam na rede pública, uma vez que podem estar acentuando desigualdades sociais pré-existentes. 


\section{REFERÊNCIAS BIBLIOGRÁFICAS}

BERENDS, Mark. Educational stratification and students' social bonding to school. British Journal of Sociology of Education, v. 16, n. 3, p. 327-352, 1995.

BOURDIEU, Pierre. Cultural reproduction and social reproduction. In: KARABEL, J.; HALSEY, A. H. (eds). Power and ideology in education. New York: Oxford University Press, p. 487511, 1977.

BOWLES, Samuel. Unequal education and the reproduction of the social division of labor. In: KARABEL, J.; HALSEY, A. H. (eds). Power and ideology in education. New York: Oxford University Press, p. 137-153, 1977.

BOWLES, Samuel; GINTIS, Herbert. I.Q. in the U.S. class structure. In: KARABEL, J.; HALSEY, A. $\mathrm{H}$. (eds). Power and ideology in education. New York: Oxford University Press, p. 215-232, 1977. BROADED, C. M. The limits and possibilities of tracking: some evidence from Taiwan. Sociology of Education, v. 70, p. 36-53, jan. 1997.

CICOUREL, A.; KITSUSE, J. The school as a mechanism of social differentiation. In: KARABEL, J.; HALSEY, A. H. (eds). Power and ideology in education. New York: Oxford University Press, p. 282-292, 1977.

CLARK, B. R. The "cooling-out" function in higher education. In: HALSEY, A. H.; FLOUD, J.; ANDERSON, C. A. (eds). Education, economy and society. New York: The Free Press of Glencoe, p. 513-523, 1961.

COLLINS, R. Functional and conflict theories of educational stratification. In: KARABEL, J.; HALSEY, A. H. (eds). Power and ideology in education. New York: Oxford University Press, p. 118-137, 1977.

COSTA, Marcio. Tempos de Deseperança: roteiro para pensar a educação quando o futuro parece sombrio. Porto Alegre: Humanas, v.24, p.186-200, 2001.

COSTA, Marcio; KOSLINSKI, Mariane. Entre o mérito e a sorte: escola, presente e futuro na visão de estudantes do ensino fundamental do Rio de Janeiro. Revista Brasileira de Educação, v. 11, n. 31, p. 133-154, 2006.
FORQUIN, Jean-Claude. Abordagem sociológica do sucesso e do fracasso escolares. In:__. Sociologia da Educação: dez anos de pesquisa. Petrópolis: Vozes, 1995.

GAMORRAN, A. et al. An organizational analysis of the effects of ability grouping. American Educational Research Journal, v. 32, n. 4, p. 687715, 1995.

KARABEL, J.; HALSEY, A. H. Education research: a review and an interpretation. In: (eds.) Power and ideology in education. New York: Oxford University Press, p. 1-86, 1977.

LIPSET, S. M.; BENDIX, R. Social mobility in industrial societies. Berkeley, L. A.: University of California Press, 1959.

MORTIMORE, P. Can effective schools compensate for society? In: HALSEY, A. H. et al. Education, culture, economy and society. New York: Oxford University Press, 2003.

MORTIMORE P. et al. School matters: the junior years. Wells: Open Books, 1988.

OAKES, J.; GUITON, G. Matchmaking: the dynamics of high school tracking decisions. American Educational Research Journal, v. 32, n. 1, p.3-33, 1995.

REIMERS, F. Perspectives in the study of educational opportunity. In:___. Unequal schools, unequal chances: the challenges to equal opportunity in Americas. Cambridge: Harvard University Press, 2000.

RIST, R. C. On understanding the processes of schooling: the contributions of labeling theory. In: KARABEL, J.; HALSEY, A. H. (eds.) Power and ideology in education. New York: Oxford University Press, p. 292-306, 1977.

SORENSEN, A.; MORGAN, S. L. School effects: theoretical and methodological issues. In: HALLINAN, M. T. (ed.) Handbook of the sociology of education. New York: Kluwer Academic/ Plenum Publishers, 2000.

SPÓSITO, Marília P. Juventude e escolarização. Brasília: COMPED/INEP/ MEC, 2002, v. 1.

Algumas reflexões e muitas indagações sobre as relações entre juventude e escola no Brasil. In: ABRAMO, H. W.; BRANCO, 
P. P. M. (orgs.). Retratos da juventude brasileira: análises de uma pesquisa nacional. São Paulo: Ed. Fundação Perseu Abramo/Instituto Cidadania, 2005.

TURNER, R. H. Modes of social ascent through education: sponsored and contest mobility. In:
HALSEY, A. H.; FLOUD, J; ANDERSON, C. A. (eds.) Education, economy and society. New York: The Free Press of Glencoe, p. 121-139, 1961. WAGNER, Peter. Liberty and discipline: a sociology of modernity. London/New York: Routledge, 1994.

Recebido em: janeiro 2008

Aprovado para publicação em: junho 2008

Marcio da Costa é Professor da Faculdade de Educação da Universidade Federal do Rio de Janeiro (marccosta@terra.com.br); Mariane C. Koslinski é Doutoranda do Programa de Pós-Graduação em Sociologia e Antropologia da Universidade Federal do Rio de Janeiro (marianecampelo@ifcs.ufrj.br; marianeck@yahoo.com). 